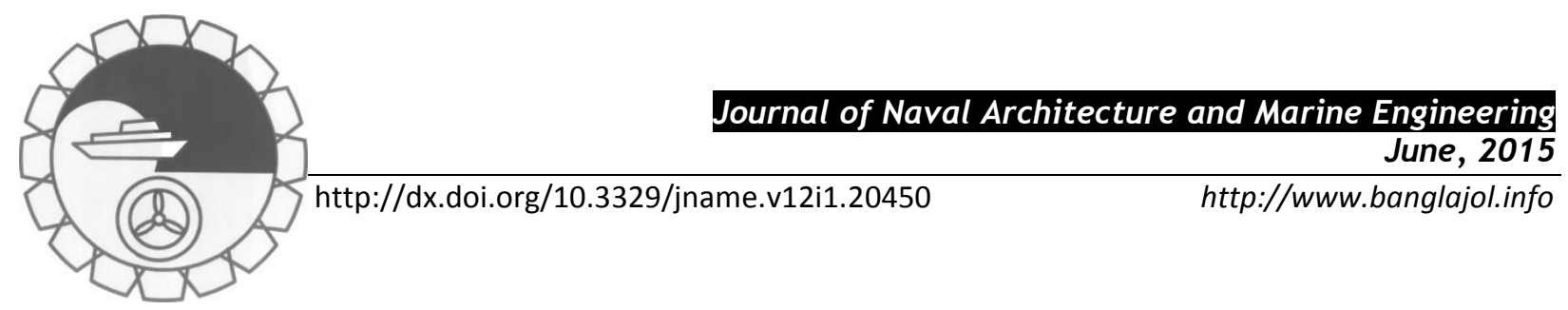

\title{
GREEN SHIP RECYCLE YARD DESIGN
}

S. Sunaryo* and D. Pahalatua

Naval Architecture Study Programme, University of Indonesia, Depok-16424, Indonesia, *Email: naryo@eng.ui.ac.id

\begin{abstract}
:
The life cycle of a ship has an age limit related to its operation. When the ship is not economically profitable any more, it will be recycled or scrapped. Since the scrapped ship has plenty of hazardous materials, special care should be carried out to manage the wastes in accordance with the national and international available regulations. With regard to this a ship recycle yard that conducts ship breaking and recycle of the ship's outfits, machineries, and infrastructure should be well designed in order to comply to all regulations that prevent it from producing harmful and polluting wastes to human and environment. The study was aimed to design an environmentally friendly or green ship recycle yard in Indonesia as a pilot project in anticipation to the booming of old used merchant ships fleet due to the implementation of cabotage principle. The proposed project is located in the Maritime Industrial Cluster in Tanggamus Regency, Lampung Province, Sumatera. The ship recycle yard is designed with a capacity of maximum 30,000 DWT ship to be recycled, and all the activities involve in the yard would comply and refer to the environmental and IMO regulations, to ensure that no harm and hazardous wastes polluting the surrounding land and sea by arranging a proper layout and providing proper facilities and working procedures.
\end{abstract}

Keywords: design, layout arrangement, ship recycle yard, environment, green, facilities.

\section{Introduction}

Indonesia is the world's largest archipelagic state with more than 17,000 islands as stated by the United Nation Convention of the Law of the Sea (UNCLOS) 1982, two third of its territory is covered by sea, therefore sea transportation plays important role for its economic and political sovereignty as well as for the logistic connectivity of the country. Since the implementation of cabotage principle in 2005 as obligated by the Presidential Instruction No. 5, 2005 the number of Indonesia's merchant ships fleet has increased very significantly from around 6,000 units in 2005 to more than 13,000 units in 2013 as stated by the Indonesia's National Ship Owners Association. According to Jibi the growth was mainly due to procurement of used ships from abroad, and around $70 \%$ of the fleet are consisted of old ships that need to be replaced with the new ones in less than 5 years time. Refereeing to these data and based on the information given by the Indonesia's National Ship-owners Association that around 5,000 out of 13,000 units of national merchant ships are dominated by container vessels and oil tankers ranging from 3,000 dwt up to 50,000 dwt and 50\% of them are in the range of 10,000 to $30,000 \mathrm{dwt}$, if it is assumed that $50 \%$ of the vessels should be recycled in 5 years time that means there are around 1,250 vessels are waiting in the market and therefore the demand for ship recycle or scrapping is promising.

In anticipation to the prospective demand the Regency of Tanggamus in Lampung Province, Sumatera is planning to build an environmentally friendly ship recycle yard in within its Maritime Industrial Estate. In conjunction with this plan a study was carried out to design and arrange a ship recycle yard with the capacity that would cater the coming demand of ship recycling and scrapping, and comply to the requirements of both national as well as international laws and regulations concerning the impacts of the activities of ship recycling yard which, include the handling, storage, and transporting of hazardous, polluting, and poisonous materials, that might harm the surrounding environment and inhabitants.

\section{Ship Recycling}

Ship recycling are the processes that take place in a ship recycle yard which involves a wide range of activities, from removing all the equipment and items left on a ship, such as engine parts and fittings, to cutting down and recycling the entire ship's infrastructure, and handling and temporarily storage the hazardous materials before dispose them completely to the safe dumping plant.

According to IL and FS Ecosmart the methods commonly used in ship recycling are as follows: 
a. In water method, i.e. the dismantling and scrapping process that are conducted while the ship is kept floating on the water, buoys and stagers are commonly used to support and maintain the buoyancy of the ship; this method requires a quay and medium size area of work.

b. On land method, i.e. the dismantling and scrapping process that are carried out ashore/on-land, this method usually makes use of high inter-tidal beach and requires a considerably large area of work, commonly used facilities for berthing are: winch, air bag/balloon, slipway, or just the existing dry land when the tide is is in the lowest level.

c. Mixed between in water and on land method, i.e. combination of in water and on land methods. Usually the superstructure and some ship machineries are dismantled while the ship is still on the water, and then the scrapping of the hull is carried out on land when the ship is light enough to be pulled ashore.

The stages of scrapping processes are usually carried out as follows:

- Ship Arrive; Ship is towed and pulled to the scrapping berth, and staggered,

- Understand and Identifying; identify and analyse the ship condition,

- Removing; all liquid materials and ship outfits are removed from the ship before the scrapping process is started,

- Dismantling and Metal Cutting; non metal parts of the ship are dismantled first before the metal parts and structure are cut using oxy acetylene flame cutting tools, the work can be divided into primary cutting and secondary cutting.

- Separation of Scrap; the scrap are sorted out and the separation of harmful material from potentially recycle or reused materials. The hazardous materials are then temporarily stored waiting to be discarded later.

The process can be illustrated as shown in Fig. 1:

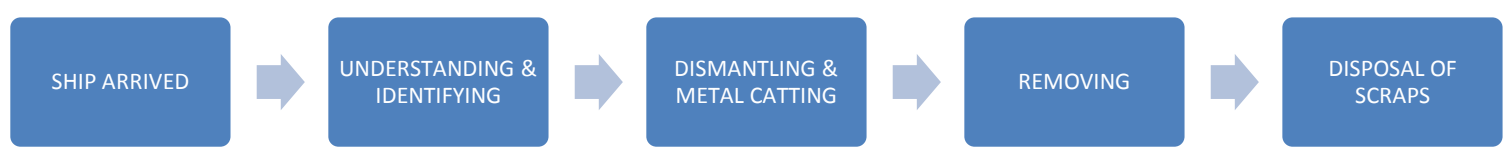

Fig. 1: Processes of ship scrapping

\section{Threats from Ship Recycling Processes and Their Preventive Requirements}

In ship recycling processes, according to International Maritime Organization (IMO) there are materials and wastes that might harm human being and polluting the environment, such wastes among other things are left over fuel and lubricating oil that are categorized as flammable liquid and pollutant, parts that content of asbestos and PCB's (polychlorinated biphenyl) that are categorized as dangerous materials that have long term effects, and might cause cancer and hormonal diseases, poisonous materials such as paint and coating, rust particles, etc.

Therefore based on the Hong Kong Convention, ship that is going to be recycled is required to undertake special survey to verify International Certificate on Inventory of Hazardous Materials or an International Ready for Recycling Certificate, or ascertain for the condition of the ship or its outfits do not correspond substantially with the particulars categorized as hazardous materials; or there is no procedure implemented on board the ship for the maintenance of the inventory of hazardous materials. Then the yard is required to provide "Ship Recycling Plan", which depended on the type, size, and the condition of the ship to be recycled. The following guidelines should be under taken as technical standards for the ship recycle yard:

- Guidelines for the Development of the Inventory of Hazardous Materials, adopted by resolution MEPC.197(62), 2011 ;

- Guidelines for the Development of the Ship Recycling Plan, adopted by resolution MEPC.196(62), 2011;

- Guidelines for Safe and Environmentally Sound Ship Recycling, adopted by resolution MEPC.210(63), 2012 ; and

- Guidelines for the Authorization of Ship Recycling Facilities, adopted by resolution MEPC.211(63), 2012 . 
Ship recycling convention is the continuation of the Basel convention 1980 on the Control of Trans-boundary Movements of Hazardous Wastes and their Disposal in protecting human health and the environment against the adverse effects which may result from such wastes.

\section{Ship Recycling Facilities}

Ship recycling facilities should have capability of recycling ship consistent to the national law as well as international conventions. The facilities should be monitored by a competent national administration in accordance with regulation developed by International labour Organization (ILO) on the Guidelines On Safety And Health In The Processes of Ship-breaking and Basel Convention on the Technical Guidelines On Environmentally Sound Control Management And Dismantling of Ship Parts.

In choosing the recycling facilities ship owner should counsel the authority and consider the guidelines on the ship recycling. Practically ship-breaking using improper facilities are not accepted because they might create residue from hazardous materials and wastes. Ship owner should discus with the recycling yard on how to dispose the hazardous materials safely.

The facilities that should be available in the recycling yard among other things are:

a. Container

Container is used to store bulk parts, it has standardized size.

b. Storage Tank

Storage tank is used to store liquid, waste storage tank should in good condition, covered, and permanently roofed. The storage tank can only be used for the containment of waste that compatible to its construction material.

c. Drainage

There are two types of drainage, i.e.:

2. Detention type; for temporary detaining water, and then flow it to a storage pool in order to maintain the balance of water.

3. Retention type; water is detained and store temporarily on the surface while give time for the water to be absorbed to the soil naturally.

\section{Yard Arrangement}

Based on the market analyses as mentioned in the introduction the yard was planned to have maximum capacity of 30,000 dwt of ship to be recycled. For this size of ship in general the average main dimensions are more or less: LOA: $\pm 180 \mathrm{~m}, \mathrm{~B}: \pm 20 \mathrm{~m}$; $\mathrm{T}: \pm 15 \mathrm{~m}$. And thus the facilities were arranged based on these references, which would consist of:

- Quay, $200 \mathrm{~m}$ long for mooring and in water scrapping, three to four ships can be moored to the quay standby for recycling.

- Primary Cutting area/berth, slipway 190m X 30m, and $200 \mathrm{kw}$ winch, for cutting the ship structure into blocks weighing maximum 20 tonnes. The slipway length was chosen based on the maximum length of 30,000 dwt ship and additional space for working allowances, and the winch capacity was estimated based on the 12,000 tonnes lightweight of ship rolled on airbags with $4^{0}$ slipway slope.

- Secondary cutting area, open area with dimensions $185 \mathrm{~m}$ X 50m, for cutting the blocks into smaller pieces equipped with drainage and underground storage tank, so that the liquid wastes will not flow into the sea but collected temporarily in the underground tanks which, will be pumped up later on to the waste water tank truck for further treatment and disposal. The dimensions of the secondary cutting area were decided based on the assumption of the major ship unit sizes to be scrapped and some spaces for ease of work and parts removal.

- Scrapping work equipment and tools, flame cutting tools and equipment, scaffoldings, hoists and tackles etc. For cutting the ship structure into smaller pieces.

- Lifting and transportation facilities, 25 tonnes safe weight lifting capacity mobile crane, forklift trucks, and trucks, for moving the ship blocks and parts from primary cutting area to secondary cutting area, and from secondary cutting area to the recycled parts storages.

- Recycle parts storages, storage for engines and outfits $30 \mathrm{~m} \mathrm{X} \mathrm{30m,} \mathrm{electric} \mathrm{and} \mathrm{electronics} \mathrm{storage} 10 \mathrm{~m}$ $\mathrm{X} 20 \mathrm{~m}$, and open air storage for scrapped metal structures $50 \mathrm{~m}$ X $30 \mathrm{~m}$. 
- Waste storage, two forty feet containers are used for temporary storage of solid hazardous wastes including asbestos containing materials, and three different liquid storage tanks dedicated for fuel oil, lubrication oil, and dirty water respectively. The hazardous wastes will then be brought to a special disposing plant run by the estate management.

- Office and other supporting facilities, office buildings, canteen, clinic, mosque, power generator, gas storage, fresh water tank, and parking ground.

- Safety appliances and facilities, fire safety appliances, oil spill prevention and recovering equipment etc.

The arrangement and layout of the recycling yard are shown in Figs. 2 and 3.

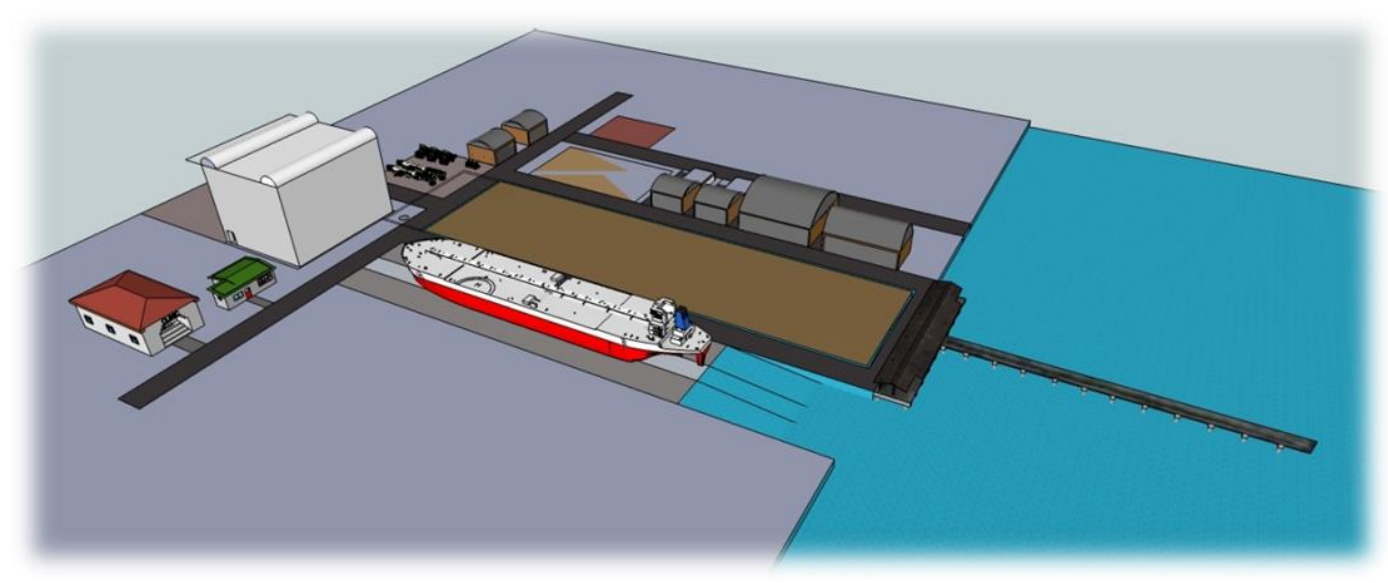

Fig. 2: Recycling yard's arrangement

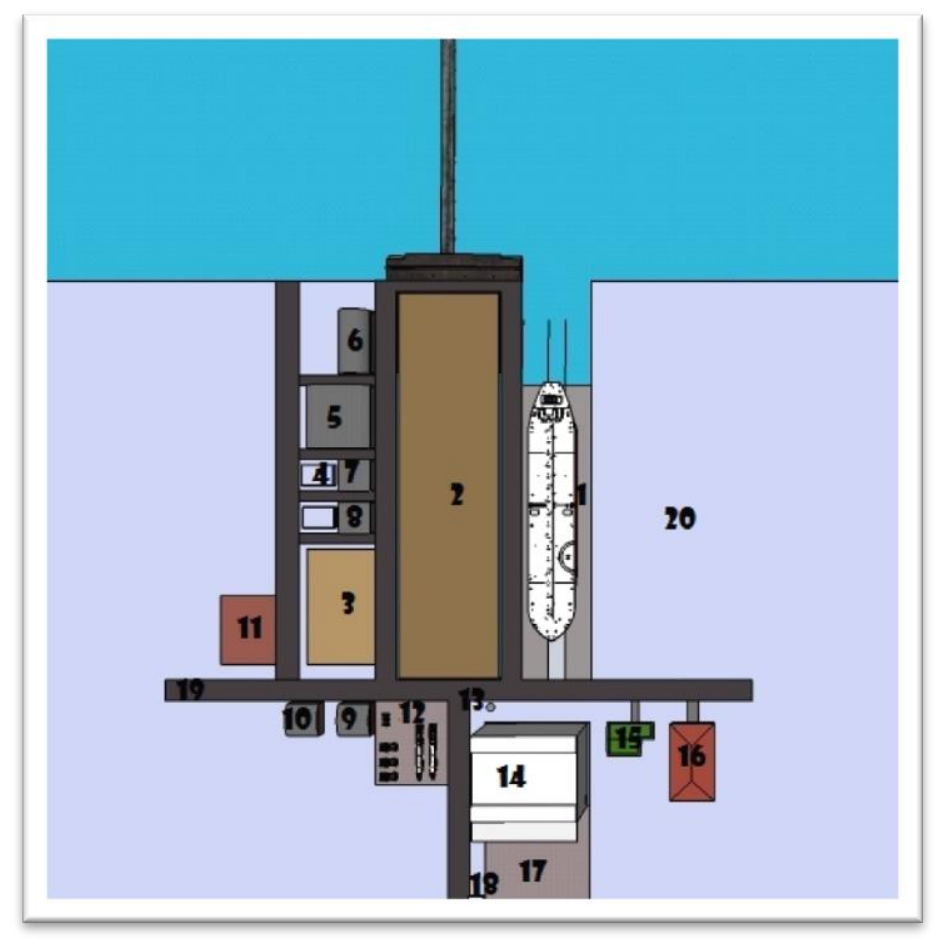

Fig. 3: Recycling yard's layout

Where the numbers are representing: 


\begin{tabular}{|c|l|c|l|}
\hline 1 & Slipway (primary cutting) & 11 & Underground storage tank \\
\hline 2 & Secondary cutting area & 12 & Facility garage \\
\hline 3 & Structural parts storage open area & 13 & Internal road \\
\hline 4 & Storage tank & 14 & Office \\
\hline 5 & Machinery and outfits storage & 15 & Canteen \\
\hline 6 & Electric and electronics storage & 16 & Clinic \\
\hline 7 & Storage for materials containing asbestos & 17 & Parking ground \\
\hline 8 & Storage for materials containing PCB's & 18 & Security post \\
\hline 9 & Scraping work facilities warehouse & 19 & Road \\
\hline 10 & Garbage (not harmful) disposal area & 20 & Future expansion plant \\
\hline
\end{tabular}

It is estimated 15 to 20 ships can be recycled per annum depending on the size and the structural difficulty of the ships to be recycled based on average 20 days for a single ship to be recycled.

\section{Conclusion}

The design of proposed recycling yard has the maximum capacity of recycling 30,000 DWT ship, the facilities and layout were arranged in order to comply to the existing national and international regulations, so that all the potential hazardous materials that would be produced from the recycling processes would be managed properly by the yard, and no pollution and dangerous substances will affect the human and surrounding environment.

\section{Acknowledgement}

This research was supported by Directorate General of Higher Education, Ministry of Research Technology and High Education, Republic of Indonesia, and Directorate of Research and Community Engagement University of Indonesia.

\section{References}

Carey Timothy (2011): The Hong Kong International Convention for the Safe and Environmentally Sound Recycling of Ships: Progress? Master Thesis, Lund University.

IL \& FS Ecosmart Limited Hyderabad. (2010): Technical EIA Guidance Manual for Ship Breaking Yards. India: Government of India.

Indonesia’s National Ship-owners’ Association (2013): Annual Report 2013.

International Labour Organization (2003): Safety and health in ship-breaking: Guidelines for Asian countries and Turkey, Interregional Tripartite Meeting of Experts on Safety and Health in Ship-breaking for Selected Asian Countries and Turkey, 7 - 14 October 2003.

International Maritime Organization (2009): Hong Kong International Convention For The Safe And Environmentally Sound Recycling Of Ships, 2009, International Conference On The Safe And Environmentally Sound Recycling Of Ships 19 May 2009.

International Maritime Organization (2011): Guidelines for the Development of the Inventory of Hazardous Materials, resolution MEPC.197(62).

International Maritime Organization (2011): Guidelines for the Development of the Ship Recycling Plan, resolution MEPC.196(62).

International Maritime Organization (2012): Guidelines for Safe and Environmentally Sound Ship Recycling, resolution MEPC.210(63). 
International Maritime Organization (2012): Guidelines for the Authorization of Ship Recycling Facilities, resolution MEPC.211(63).

International Maritime Organization (2014): Recycling of Ships,

http://www.imo.org/OurWork/Environment/ShipRecycling.

Jibi (2010): Competitiveness of National Shipbuilding Industry is Still Low (in Indonesian): Bisnis Indonesia News Paper 14 April 2010.

Lampung Provincial Office (2012): Lampung Province's 2011 - 2031 Master Plan, http://www.investasi.lampungprov.go.id/kabupaten-tanggamus.html.

Secretariat of the Basel Convention/UNEP (2007): The Global Programme for Sustainable Ship Recycling, http://www.basel.int/Portals/4/Basel\%20Convention/docs

Secretary of State, Republic of Indonesia (1985): Indonesian Law No. 17, 1985 on The Ratification of United Nation Convention of the Law of the Sea (UNCLOS) 1982.

Secretary of State, Republic of Indonesia (2005): Presidential Instruction No. 5, 2005 on The Empowerment of National Shipping Industry.

U.S. Environmental Protection Agency (2000): A Guide for Ship Scrappers: Tips For Regulatory Compliance. 